\title{
Synergetic Transpedicular Device with Dynamic Beams from the Alloy with Shape Memory Effect
}

\author{
S Acampora ${ }^{1 *}$, FM Acampora ${ }^{2}$, M Kollerov² ${ }^{2}$ AA Ilyin ${ }^{2}$ and GP Cantore ${ }^{1}$ \\ ${ }^{1}$ Neurosurgical Department, IRCCS Neuromed Institute, Italy \\ ${ }^{2}$ Materials Science and Technology of Materials Department, MATI Russian State Technological University, Russia \\ Submission: March 11, 2017; Published: May 30, 2017
}

*Corresponding author: Sergio Acampora, Neurosurgical Department, IRCCS Neuromed Institute, via Alessandro Manzoni 216-80123 Napoli (Italy), Tel: +39-333-784-7109/39-081-5750276; Email: sergioacampora@tin.it

Summary

The authors present the titanium pedicle screw and Nitinol rod system for spine stabilization.

Keywords: Vertebral instability; Spondylolisthesis; Spinal internal stabilization; Nickel-titanium device spinal surgery; Dynamic stabilization; Nitinol; Nickel-titanium device

\section{Introduction}

Recently, several types of devices for the rear dynamic stabilization have been introduced as an alternative to fusion devices for the surgical treatment of lumbar spine degenerative or traumatic [1]. It is hypothesized that the use of elastic materials such as Nitinol can restore the stability of the lumbar spine without the adverse effects of the stress-shielding that are often found with the 'rigid devices' [2-5]. Many studies have shown that the devices made of elastic material can be able to maintain a kinematic behavior of the normal spine with the optimal load sharing between the front and posterior spinal elements $[6,7]$. Materials and Methods

The innovative component of this system (RodFix) is the material of the bars that possesses two characteristics: the shape memory, for the correction of some deformity of the spine, and superelasticity, for the maintenance of functional mobility of the operated segment (Figure 1). The difference between the RodFix and the other of screws and rods systems, commonly used in spinal surgery, therefore consists in the ability of the RodFix to amortize the loads without transferring them to the plant ends, reducing the distabilità junctional that usually can occur after one / two years after surgery [8]. The system "RodFix" is indicated in the stabilization of the back-lumbar spine in the case of vertebral fracture, traumatic and pathological; olistesi; deformity of the spine and in all cases where there is a condition of instability or distabilità, with or without stenosis of the channel or when you want to realize a bypass of forces [9-11].
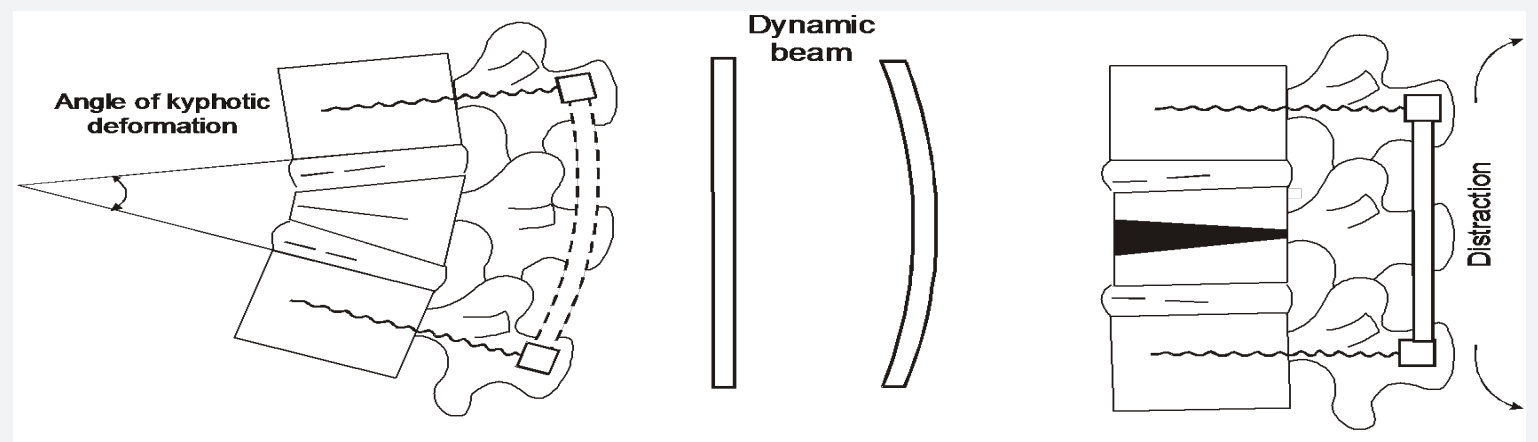

Figure 1: This picture shows the application of RodFix system. 


\section{Open Access Journal of Neurology \& Neurosurgery}

\section{Results}

A total of 8 patients ( 3 males and 5 females) with a mean age of 53.3 years (ages 42 to 68 years) were treated at IRCCS Neuromed Institute, Pozzilli (IS), Italy, during the years 20052007, for spondylolisthesis (5 cases), post-traumatic vertebral instability (1), post-surgery vertebral instability (2) (Figure 2).

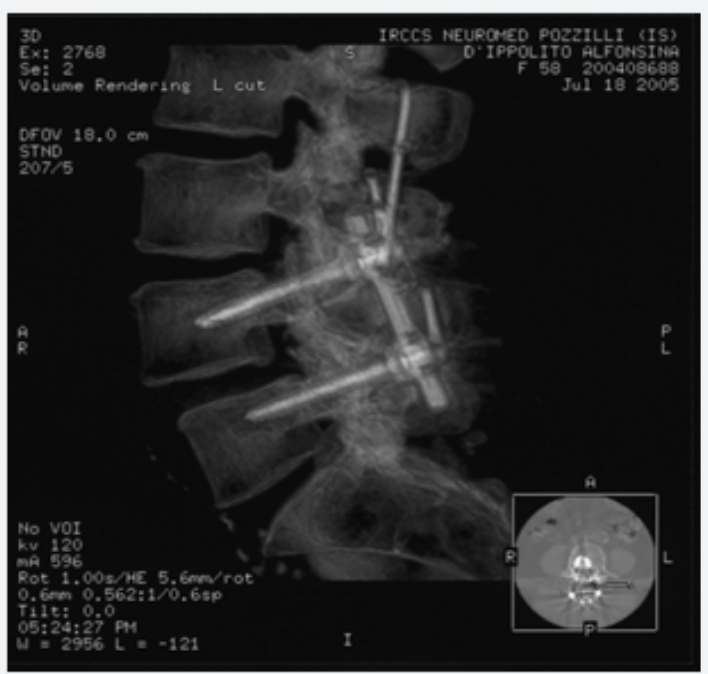

Figure 2: Illustrative post-operative case. MRI scan showing the application of RodFix system at L4L5 and LumbarFix at L3L4.

\section{Discussion and Conclusions}

The main advantages of this stabilization system in compression fractures of the vertebral bodies are represented primarily by the ability to distract the spine injured segment thanks to the effect of the shape memory in each bars Nitinol.

In conclusion conforming to the studies made in laboratory on animals and clinical trial on man it can be said that the nickeltitanium for spinal fixation defined "RodFix" satisfy fully the fundamental structural properties needed to allow a convenient fixation of the vertebral column and a neuroradiological test (CT, $\mathrm{Rx}, \mathrm{MRI}$ and so on) without artefacts and distorsions of image $[11,12]$.

\section{References}

1. Bortoluzzi M (1989) Rachis instability: stabilization techniques. Neurosurgery winter week, Sestriere, Italy.

2. Ilyin A, Kollerov M, Gusev D, Davidov E, Gazzani R (1999) Production and application features of implants from Nitinol with the shape memory effect. Titanium' 99: science and technology: 1223-1229.

3. Ilyin AA (2004) Materials with "memory of form" in spinal surgery. $1^{\text {st }}$ Meeting Italy-Argentina, Naples, Italy.

4. Panjabi MM, Oxland T, Takata K, Goel V, Duranceau J, et al. (1993) Articular facets of spine: quantitative three-dimensional anatomy. Spine 18(10): 1298-1310.

5. Panjabi MR (1987) Spine bio-mechanics. In Wilkins RH: Neurosurgery, Medical Books.

6. Acampora S, De Marinis P, Del Gaizo C, Amoroso E (1999) Application of shape memory Titanium-nikelide in spinal surgery. Journal of Surgical Oncology Supplement 4: 72.

7. Acampora S, Troisi AA (2004) Rachis elastic fixation. Neurobiology Italian Journal, Suppl 01-2: 111.

8. Rabischong P (2004) Il concetto di instabilità (Instability), $3^{\text {rd }}$ European Course on Minimally Invasive Spinal and Peripheral Nerve Surgery, Treviso, Italy.

9. Acampora S, Isidori A, Kollerov M, Ilyin AA, Cantore GP (2005) Synergetic transpedicular device with dynamic beams from the alloy with shape memory effect. $13^{\text {th }}$ World Congress of Neurosurgical Surgery, Marrakesh, Morocco.

10. Acampora S, Troisi AA (2004) Rachis elastic fixation. Neurobiology Italian Journal, Suppl 01-2: 111.

11. Acampora S, De Marinis P, Ambrosio G, Palmieri A (1999) NickelTitanium in neurosurgery: neuroradiological aspects. Neuroradiology Journal 12(Suppl 4): 99.

12. Troisi AA, Di Mizio R, Acampora S (2000) Nickel-Titanium implants for rachis surgery: considerations on riabilitative treatments. $87^{\text {th }}$ Congress of Orthopedy and Traumatolgy Society in Southern and Insular Italy (SOTIMI), Collection of acts, pp. 152-153.

Your next submission with Juniper Publishers
will reach you the below assets
- Quality Editorial service
- Swift Peer Review
- Reprints availability
- E-prints Service
- Manuscript Podcast for convenient understanding
- Global attainment for your research
- Manuscript accessibility in different formats
( Pdf, E-pub, Full Text, Audio)
- Unceasing customer service
Track the below URL for one-step submission
https://juniperpublishers.com/online-submission.php

https://juniperpublishers.com/online-submission.php 